\title{
Study on the Pattern of Subject Oriented Education
}

\author{
Yang Zhao \\ Department of Mechanical and Electrical Engineering, Guangdong University of Science \& Technology, \\ Dongguan, China
}

Keywords: subject oriented education; traditional education; the goal of training; teaching design

\begin{abstract}
The traditional teaching with teachers as the center means that teaching design depends mainly on what teaching, teaching process and evaluation mainly depends on how to teach, which has greatly restricted students' subjective initiative and reduced their interest and enthusiasm in learning. This paper puts forward the pattern of subject oriented education with the main emphasis on the teaching of scientific knowledge by teachers, and the classroom teaching mainly in school transformed to the cultivation of student-centered engineering practice ability, engineering thinking, and engineering innovation ability.
\end{abstract}

\section{Introduction}

In traditional education, knowledge and ability are incompatible and lack of hands-on skills [1]. The students are dull and lack of creative ability for learning; they pay attention to individual learning and neglect teamwork [2]. In the 12 graduation requirements for graduates, engineering education professional certification standards not only require engineering knowledge and engineering ability, but also emphasize general ability and moral ethics, mainly including communication and team cooperation, as well as social responsibility, engineering ethics and other aspects. In curriculum teaching, we need to reform teaching methods and assessment methods, pay attention to cultivating students' innovative ability [3], and examine students' ability to analyze and solve problems [4]. For engineering majors, the degree of mastery and application of electrical knowledge directly affects students' innovative ability [5]. In the traditional course teaching, it pays more attention to the students' electronic technology knowledge, and pays little attention to the engineering application ability, innovation ability, communication, team cooperation and engineering quality.

\section{Comparison between Subject Oriented Education and Traditional Education}

\subsection{Learning orientation}

Subject oriented education is mainly performance oriented, that is, students' learning goals, teaching content, teaching process, teaching evaluation and graduation standards are all guided by results. Traditional education mainly shows process orientation. It emphasizes students' learning according to prescribed procedures, timetable, time and progress.

\subsection{Chance of success}

Subject oriented education expands opportunities for success. To ensure the success of all students, schools should provide appropriate learning opportunities for each student. Traditional education limits opportunities for success, and learning is limited by prescribed procedures and timetables, thus their chances of success is limited.

\subsection{Achievement performance}

Subject oriented education shows the peak performance of students in the final results, and the phased results can only serve as a reference for the next stage of learning. Traditional education measures the final achievement of students based on the cumulative average result of stage learning. The poor performance at a certain stage will affect the final achievement. 


\subsection{Teaching strategy}

Subject oriented education emphasizes integration and collaborative teaching. Teachers should cooperate and strengthen communication and cooperation in a long-term manner. Through reinforcement of cooperative learning and encouragement of teamwork, a learning community is formed. Traditional education focuses on discipline, and teachers have clear boundaries, few communication and cooperation. The competitive learning and encourage each other to compete should be strengthen.

\subsection{Teaching model}

Subject oriented education embodies the ability oriented teaching model, emphasizes what students can learn and what they can do, pays attention to output and ability, and encourages critical thinking, reasoning, evaluation, feedback and action. Traditional education embodies the knowledge oriented teaching mode, emphasizing what teachers teach, attaching importance to input and paying attention to the acquisition and arrangement of knowledge.

\subsection{Teaching center}

Subject oriented education centred student. Teachers combine specific situations and apply teamwork and synergy to help students learn. Traditional education takes teachers as the center, teachers teach students what to learn, and students learn according to teachers' requirements.

\subsection{Evaluation method}

Subject oriented education embodies evaluation and learning achievements, ability oriented and multiple evaluation. Traditional education embodies evaluation and stipulate procedure, knowledge orientation and common classroom test.

\subsection{Reference standard}

Subject oriented education achieves self standard reference, focusing on the student's highest performance standards and their connotations. Traditional education achieves common standard reference, and evaluation can be used for comparison among students.

The experience comparison about students between subject oriented learning and traditional learning is shown in Table 1.

Table 1 Student experience comparison between subject oriented learning and traditional learning

\begin{tabular}{|c|c|c|}
\hline $\begin{array}{l}\text { Learning } \\
\text { experience }\end{array}$ & Traditional education & Subject oriented education \\
\hline \multirow{2}{*}{$\begin{array}{l}\text { Learning } \\
\text { role }\end{array}$} & Passive & Active \\
\hline & Mastered knowledge & Learning output \\
\hline $\begin{array}{c}\text { Learning } \\
\text { style }\end{array}$ & Memorize by rote & $\begin{array}{l}\text { Critical thinking, reasoning, and } \\
\text { reflection }\end{array}$ \\
\hline $\begin{array}{l}\text { Learning } \\
\text { plan }\end{array}$ & $\begin{array}{l}\text { Disciplinary knowledge } \\
\text { decomposed into units }\end{array}$ & $\begin{array}{l}\text { Integrated knowledge associated with } \\
\text { actual needs }\end{array}$ \\
\hline $\begin{array}{l}\text { Learning } \\
\text { process }\end{array}$ & $\begin{array}{c}\text { The content of learning is placed in } \\
\text { a strict time frame }\end{array}$ & $\begin{array}{c}\text { Learners learn according to their own } \\
\text { rhythm }\end{array}$ \\
\hline $\begin{array}{l}\text { Learning } \\
\text { motivation }\end{array}$ & $\begin{array}{l}\text { Teachers are responsible for } \\
\text { learning }\end{array}$ & $\begin{array}{l}\text { Students are responsible for their own } \\
\text { learning, motivated by continuous } \\
\text { feedback and positive self-worth. }\end{array}$ \\
\hline
\end{tabular}

\section{The Determination of the Training Target}

Based on the 12 graduation requirements and the CDIO ability outline of subject oriented education, the students' expectations for graduation are fully understood and the joint participation of all stakeholders (teachers, students, enterprise engineers, alumni, industry experts, managers and so 
on) is shared and the level of knowledge, ability and quality should be achieved by the students when they graduate. In order to improve the students' practical ability, engineering application ability and innovation ability, the comprehensive ability of engineering in electronic technology courses is formulated, and the goal of ability training is shown in Table 2.

Table 2 The goal of training and the ability of the curriculum

\begin{tabular}{|c|c|c|}
\hline Target & First level target & Two level target \\
\hline \multirow{2}{*}{ Knowledge } & $\begin{array}{l}\text { Engineering basic } \\
\text { knowledge }\end{array}$ & Scientific knowledge \\
\hline & Related subject knowledge & Engineering knowledge \\
\hline \multirow[t]{3}{*}{ Ability } & $\begin{array}{l}\text { Engineering analysis and } \\
\text { judgment ability }\end{array}$ & $\begin{array}{l}\text { Engineering problem } \\
\text { identification analysis, } \\
\text { estimation and qualitative } \\
\text { analysis, solutions and } \\
\text { suggestions }\end{array}$ \\
\hline & Engineering practice ability & $\begin{array}{l}\text { Hands-on ability and } \\
\text { flexibility }\end{array}$ \\
\hline & $\begin{array}{c}\text { Engineering innovation } \\
\text { ability }\end{array}$ & $\begin{array}{l}\text { Innovation consciousness and } \\
\text { creative thinking }\end{array}$ \\
\hline \multirow{2}{*}{$\begin{array}{l}\text { Comprehensive } \\
\text { quality }\end{array}$} & Individual and team & $\begin{array}{l}\text { Organizational, coordination, } \\
\text { communication and } \\
\text { leadership skills. }\end{array}$ \\
\hline & Logical thinking ability & $\begin{array}{c}\text { Oral expression } \\
\text { Written expression }\end{array}$ \\
\hline \multirow{2}{*}{$\begin{array}{l}\text { Engineering } \\
\text { attitude }\end{array}$} & Learning attitude & $\begin{array}{l}\text { Attendance and task } \\
\text { completion }\end{array}$ \\
\hline & $\begin{array}{l}\text { Attitude towards complex } \\
\text { engineering problems }\end{array}$ & $\begin{array}{l}\text { Analysis capability and } \\
\text { scheme design }\end{array}$ \\
\hline
\end{tabular}

\section{Instructional Design}

In the subject oriented education model, it is emphasized that the educator should first consider the goals that the students should achieve when they graduate, and then build the curriculum goals and select the content of the curriculum in the opposite direction. The teaching design based on subject oriented education, as shown in Figure 1, mainly includes the following links: (1) formulating the expected "learning output" in the professional level and determining the training objectives; (2) to determine the content of the curriculum through an integrated curriculum design; (3) to determine the expected "study production" at the course level and to design a suitable teaching strategy; (4) assess the actual "learning output" at the professional level and the curriculum level.

The goal oriented engineering education emphasizes the following four aspects in teaching design and Implementation: the training goal should be guided by demand, the requirements of graduation should be guided by the training goal, the course teaching should be guided by the requirements of graduation, and the allocation of resources should be guided by the achievement of the requirements of graduation and the goal of training. Graduation requirements should be able to support the achievement of training objectives, and the achievement of teaching requirements should support the achievement of graduation requirements. All the teachers who participate in the teaching should make clear the contribution and responsibility that they teach to the requirements of graduation and the goal of training. Each student should make clear the role that they have learned to achieve the requirements of graduation and the goal of training. The presentation of training objectives and graduation requirements should help to evaluate the achievement of goals and requirements. 


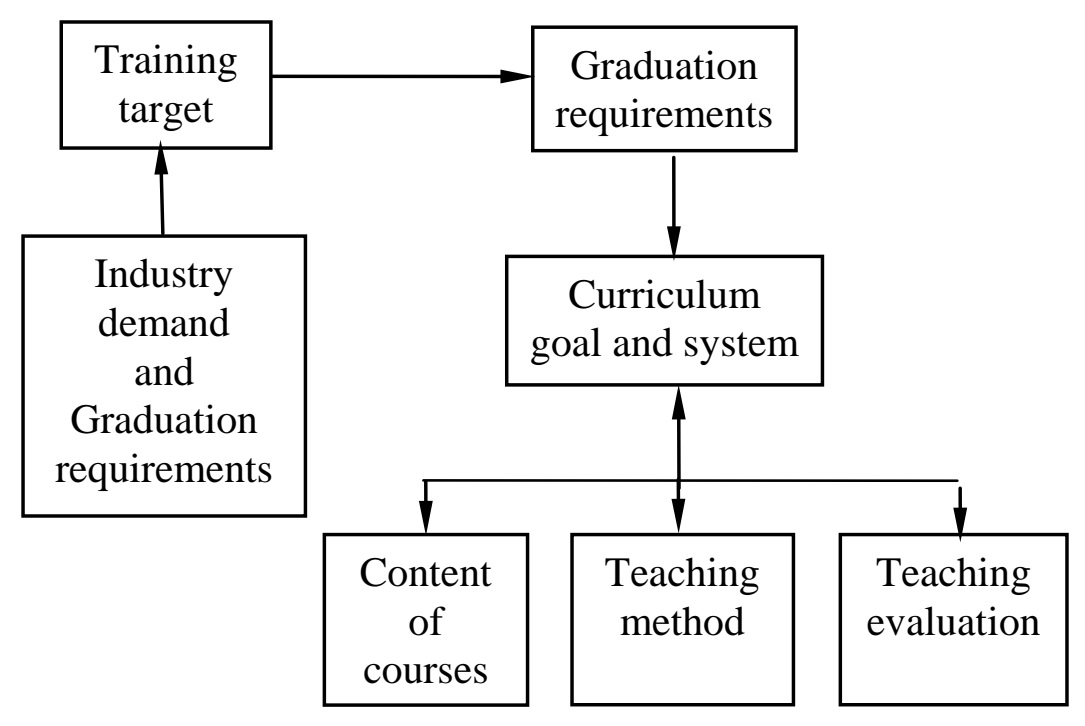

Figure 1. Teaching design based on subject oriented education

\section{Summary}

Local colleges and universities should speed up the accreditation of engineering education and promote the reform of education and teaching according to the international advanced concepts and the pace of integration between universities and the international community. The professional level of learning output and the integrated curriculum system should be cleared. The process of preparing certification for certified professional is actually the process of fully mobilize and actively implement classroom reform. Certification emphasizes the result oriented training of professional talents, which requires teachers to implement effectively in curriculum teaching.

\section{Acknowledgement}

This work was financially supported by the Project of Higher Education Reform in Guangdong University of Science \& Technology.

\section{References}

[1] R Zhou, NA Gui-Ling. Study on the Construction of Education Pattern for Professional Ethics in Application-oriented Universities Based on the Appeals of Student Subject. Journal of Heilongjiang College of Education, Vol.9 (2014), p. 73.

[2] JY Xie. Discuss on Subject-oriented Teaching in Physical Education Curriculum in Universities and Colleges. Journal of Chengdu Sport University, Vol.22 (2016), p. 32.

[3] Z Zhong, LI Yiming.Teaching the Subject of Robot and Creativity-Oriented Education in Higher Vocati onal Education. Journal of Shenzhen Polytechnic, Vol.21 (2008), p. 52.

[4] M Palkina. Subject-Oriented Education for Countryside Schools Senior Students Based On the Innovative Educational System. Bulletin of Miyagi University of Education, Vol.1 (2013), p. 49.

[5] XD Meng, YX Zhou. Construction of Graduation Requirements for Microelectronics Science and Engineering Based on Engineering Education Certification. Education Teaching Forum, Vol.42 (2018), p. 132. 